\title{
RETIREMENT SAVING BEHAVIOUR OF YOUNG ADULTS IN THE FINANCIAL SERVICES SECTOR
}

\author{
Hugue Nkoutchou* \\ University of Johannesburg \\ ugue397@gmail.com \\ Riëtte Eiselen\# \\ University of Johannesburg \\ rjeiselen@uj.ac.za
}

February 2012

\begin{abstract}
In a society characterised by high levels of consumption that result in high levels of debt, saving sufficiently for retirement represents a major challenge, especially in light of the steadily increasing cost of living and the cost associated with healthcare. Questions regarding the extent to which retirees have accumulated sufficient money during their working years to support them are being raised. The purpose of this exploratory study was to investigate the behaviour of young adults in relation to retirement provision. A web-based survey was conducted in a single large organisation. The findings revealed that young adults tend to have a wide range of debt. Although they are aware that the funds accumulated in their retirement funds would not provide sufficient cover during retirement, they tend not to save over and above the minimum contribution to their employing organisation's retirement fund. Organisations should encourage young adults to reduce their debt and voluntarily save for retirement.
\end{abstract}

\section{Keywords}

Young adult, retirement, saving, behaviour, South Africa.

\footnotetext{
*Mr Hugue Nkoutchou is a masters graduate of the Department of Finance \& Investment Management at the University of Johannesburg, South Africa.

\#Prof Riëtte Eiselen is associate professor in the Department of Finance \& Investment Management at the University of Johannesburg, South Africa.
} 


\section{INTRODUCTION}

In South Africa, saving sufficiently for retirement remains a major challenge, with both a high level of debt among individuals and society being consumption-driven. The number of people in South Africa who are in the age group 60 and above is increasing: while approximately 3.3 million were 60 years or older in 2001 (Statistics South Africa, 2005), approximately 3.7 million were 60 or older in 2009 (Statistics South Africa, 2009), signalling an increase of $12 \%$ in the number of people aged 60 and above from the period 2001 to 2009.

An increasing risk of ill health is associated with old age. The cost associated with healthcare is increasing: while the price increase in healthcare was, on average, approximately $5.5 \%$ per annum in 2008, it was, on average, approximately $10.8 \%$ in 2009 (South African Reserve Bank, 2010). The increasing costs lead to increasing costs associated with health insurance in South Africa (South African Reserve Bank, 2009). In addition to increased healthcare costs, the costs associated with fuel, food, transport and electricity are also steadily increasing (South African Reserve Bank, 2009). The increase in the cost of living is reflected in the consumer price index $(\mathrm{CPI})$, i.e. the average-annual increase in the price of selected goods and services. While CPI decreased below $6 \%$ towards the end of 2009, it is expected to increase to above $6 \%$ in the future (South African Reserve Bank, 2010), due to, among other things, the increases in electricity tariffs (South African Reserve Bank, 2010). The increases of 2011 and 2012 illustrate the changes in the cost of living in recent years.

The above suggests the importance for adults in South Africa to make sufficient provision for their retirement. However, a large number of people do not make adequate provision for their retirement (Kotze \& Smit, 2008; Genesis Analytics, 2008). Indeed, South Africans in general tend not to save adequately for their retirement, as only an estimated $6 \%$ of South Africans retire financially independent, as reported by Strydom (2007). Not making adequate provision for retirement is not limited to South Africa alone. Studies conducted in the United States of America and the United Kingdom revealed that individuals there also tend not to save for retirement (Thomas, Jones, Davies and Chilvers, 2009; Adami and Gough, 2008; Shapiro, 2004; Lusardi, 2001). In this regard, Snyder (2010) reported that approximately $36 \%$ of Americans do not save for retirement and that nearly $50 \%$ of Americans arrive at retirement age with little or no money.

The question that arises is why individuals do not make adequate provision for their retirement. Although research has been conducted in the United States of America and the United Kingdom about the behaviour of people towards saving for retirement, little research in this regard has been done in South Africa: research conducted in South Africa includes the studies conducted by Prinsloo (2000), Kotze and Smit (2008) and Genesis Analytics (2008). Their findings revealed that a large number of individuals (nearly $33 \%$ of Life Style Measure categories 1 to 5 , a categorisation that represents approximately $74 \%$ of South Africans) (Genesis Analytics, 2008) do not make adequate provision for their retirement (Prinsloo, 2000; Kotze \& Smit, 2008; Genesis Analytics, 2008).

While a large proportion of the research studies have explored the savings behaviour of individuals who are close to retirement and at retirement age, very little research on the behaviour of young adults in particular has been conducted (Hershey, Jacobs-Lawson, McArdle \& Hamagami, 2008). This is despite the fact that those who do not start saving for retirement at a young age may jeopardise their chance of being financially secure at retirement (Shapiro, 2004). 
The primary objective of this study is to investigate the behaviour of young adults in relation to retirement saving in the South Africa context.

\section{THEORETICAL FRAMEWORK}

According to the Reserve Bank (2010), South Africans have a poor record of saving. Kotze and Smit (2008) reported that approximately $1 \%$ to $2 \%$ of disposable income is saved. According to Prinsloo (2000), the gross saving by households as a percentage of gross domestic product declined from approximately $9.1 \%$ in the period from 1960 to 1972 , to $4.2 \%$ in the period from 1990 to 1999 , while it was at a level of $1.5 \%$ in both the fourth quarter of 2010 and the first quarter of 2011 (South African Reserve Bank, 2011).

In addition, the debt-to-income ratio (i.e. the ratio of household debt to disposal income) is high and has remained high (Kotze \& Smit, 2008; Strydom, 2007; Prinsloo, 2000). The increase in household debt (or excessive debt) necessarily has a negative impact on the savings of households. Indeed, there is an inverse relationship between savings and debt. This is evident from the fact that household debt to disposal income increased from approximately $60 \%$ to $76.8 \%$ in the period 1985 to the first quarter of 2011 while savings decreased. Approximately $1.5 \%$ of disposal income was saved in the first quarter of 2011, which represents a decline compared to previous years (South African Reserve Bank, 2011).

South Africans not only tend not to save in general: they tend not to save specifically for their retirement. After retirement, individuals are usually no longer economically active and need to have sufficient funds to support themselves or continue economic activity. This is especially true if the individual wishes to maintain the same lifestyle after retirement (Shapiro, 2004). Not only do South Africans save very little for retirement, they also spend the majority of their disposal income on consumption and debt payments (Kotze \& Smit, 2008). The result is that many households arrive at retirement with little or no savings: only a small percentage (estimated to be approximately $6 \%$ ) of South African retirees are reported to be in a position to maintain the same lifestyle at the time of retirement (Strydom, 2007).

Worldwide, governments acknowledge that saving for retirement is vital, and they require companies to automatically enrol employees in retirement schemes in order to overcome the inertia that currently characterises behaviours towards saving for retirement and to make it easier for individuals to save for their retirement (South African Reserve Bank, 2011, Thomas, Jones, Davies \& Chilvers, 2009; Thaler \& Benartzi, 2007). In the United Kingdom, for example, employees will automatically be enrolled into pension schemes from 2012 provided that they are aged between 22 and the state pension age, have gross annual earnings of $£ 5035$ or more and are not already a member of a registered pension scheme (Thomas et al., 2009). Furthermore, research has shown that individuals usually do not drop out of a retirement plan voluntarily once enrolled (Thaler \& Benartzi, 2007).

In South Africa, automatic enrolment in a pension plan is compulsory for those individuals employed in an organisation. In addition, the pension plan should be approved by the South African Revenue Service (Botha, Du Plessis, Du Preez, Geach, Nel, Rossini \& Linde, 2008).

Unfortunately, automatic enrolment in a pension scheme does not necessarily imply that individuals have sufficiently provided for their retirement or that they have taken wise decisions about how much to save to sufficiently provide for their retirement (Bajtelsmit, 2006). Another disadvantage of automatic enrolment, cited in Thaler and Benartzi (2007), is the fact that the 
employees may choose the lowest possible contribution rate just to comply with their employer's policy. There is, however, a need for individuals who have joined their employer's fund to prepare for retirement over and above the mandatory requirement due to the fact that the compulsory system may not provide sufficient funds to enable employees to continue their lifestyle at the time of retirement (Wills \& Ross, 2002).

The consequences of being inadequately financially prepared for retirement are forced economic activity after retirement, lowering of living standards, reliance on government aid (such as, for example, the State Old Age Grant - Botha et al., 2008) or reliance on family and friends for financial assistance. A poor record of savings may not only have a negative impact at the level of the individual, but ultimately impacts the future consumption level of the economy. An economy's future consumption level will stay constant if individuals have accumulated sufficient savings during earning years to maintain consumption levels during the time of retirement.

\subsection{Factors that affect retirement saving behaviour}

A plethora of factors that affect retirement saving behaviour have been explored, and the majority of these relate to bio- and demographic characteristics of individuals. Other factors such as access to information and behavioural factors such as financial risk tolerance have also been investigated. In terms of bio- and demographic factors, the following have been shown to be related to retirement saving:

a) Income or wealth (Dummann, 2008; Bailey et al., 2003; Friedman \& Scholnick, 1997 in Hershey et al., 2008): the higher the income of an individual or the wealthier the individual is, the greater the individual's ability is to save and the more likely the individual is to save for retirement

b) Age (Dummann, 2008; Wills \& Ross, 2002): the older individuals are, the more likely they are to save for retirement. This tendency may be a result of greater wealth or a realisation that retirement is imminent. In contrast, young adults tend to save very little for retirement; their savings are mostly for short-term goals (Nzier, 2007; Shapiro, 2004). The reason for this behaviour is attributed to the fact that they perceive retirement to be a long way off, and, secondly, they have limited financial resources to save (Genesis Analytics, 2008; Nzier, 2007). In this regard, Shapiro (2004) noted that those who do not start saving for retirement at a younger age may jeopardise their chance of a financially secure retirement. Thomas et al. (2009) claim that young adults tend to be over-confident about the future, and, as a result, avoid saving for retirement.

c) Education (Dulebohn \& Murray, 2008; Thaler \& Benartzi, 2007; Bailey et al., 2003; Denis, 1984 in Turner, 1989): the higher the level of education, the more likely individuals are to save for retirement. Well-educated individuals not only have a greater earning potential, they also have the ability to understand and plan for their retirement (Dulebohn \& Murray, 2008). As far as attitude is concerned, people who are well educated tend to wish for a secure future, and are thus more likely to plan for retirement (Hershey et al., 2008; Beck, 1984 in Turner, 1989).

d) Employment status: due to their higher earning power, employees with a high level of seniority or with a high occupational status are more interested in saving for retirement than those at lower levels of seniority or with lower occupational status 
(Beck in Turner, 1989; Heron \& Burgess in Goudy et al., 1980).

e) Gender: males tend to be more interested in retirement issues than females (Bernasek \& Shwiff in Dulebohn \& Murray, 2008; Powell \& Ansic in Adami \& Gough, 2008; Turner, 1989). As far as behaviour is concerned, males also tend to save more than females (Hershey et al., 2008).

f) Marital status: married people are more likely to save than unmarried people (Mutran et al. in Foster, 2008).

Other factors that have been shown to be associated with retirement saving behaviour include availability of advice and financial risk tolerance. Individuals who seek advice about retirement from someone in their environment, such as a friend or family member (Friedman \& Scholnick in Hershey et al., 2008; Burns \& Dwyer, 2007) are more likely to make poor financial decisions than those seeking advice from a professional financial adviser. Individuals who have a high financial risk tolerance are more likely to invest in risky financial products such as the equity market (Friedman \& Scholnick, 1997 in Hershey et al., 2008). Although their return may be higher on these investments, the risk associated with such investments is also high. This overexposure to the equity market may have a detrimental effect on retirement savings when the individual is close to retirement age. Such an investor is more likely to lose money than a person who is more risk averse, especially when nearing retirement age.

\section{RESEARCH DESIGN}

This study was exploratory (i.e. aims at gaining insight) as well as descriptive in nature, and was done using a quantitative approach by means of a cross-sectional survey (i.e. gathering information from individuals at a single point in time). A web-based survey was carried out (i.e. the questionnaire was posted online) in a single large financial organisation in Johannesburg (South Africa). The organisation employs approximately 6000 people with different types of expertise and at different levels of seniority and experience.

\subsection{Research objectives}

The primary objective of this study was to investigate the retirement saving behaviour of young adults aged 25 to 35 years old. The research objectives at the secondary level are: research objective \#1: Describe the behaviour of young adults towards saving for retirement; research objective \#2: Compare groups of individuals according to background variables (gender, level of education, job level and financial responsibility) in terms of their retirement saving behaviour.

\subsection{Research instrument}

A structured questionnaire served as the research instrument. The questions forming part of the questionnaire were based on information gleaned from the literature and have been shown to relate to retirement savings. The questionnaire comprised three sections of mostly closedended questions. Section one related to bio- and demographic characteristics such as marital status, age, gender, race, job level, level of education, number of years of experience, basis of employment and financial responsibility in terms of number of dependants. Due to the fact that a person's level of indebtedness has been shown to be related to retirement savings behaviour, questions related to the amount of debt were also included in this section (TABLE $\mathbf{1}$ ). 
TABLE 1: Questions related to indebtedness

\begin{tabular}{|c|c|c|c|c|}
\hline $\begin{array}{c}\text { In comparison with your monthly } \\
\text { income, to what extent do you currently } \\
\text { have... }\end{array}$ & Not at all & $\begin{array}{l}\text { Very little } \\
\text { (i.e. less } \\
\text { than } 10 \% \text { of } \\
\text { your } \\
\text { monthly } \\
\text { salary) }\end{array}$ & $\begin{array}{c}\text { Moderate } \\
\text { debt (i.e. } \\
\text { between } 10 \\
\text { and } 30 \% \text { of } \\
\text { your } \\
\text { monthly } \\
\text { salary) }\end{array}$ & $\begin{array}{c}\text { A great deal } \\
\text { of debt (i.e. } \\
\text { more than } \\
30 \% \text { of your } \\
\text { monthly } \\
\text { salary) }\end{array}$ \\
\hline
\end{tabular}

Credit card debt?

An overdraft on your current account?

Debt at retail stores?

Home loan repayment debt?

Car repayment debt?

Rental debt?

\section{Source: Survey instrument developed by researchers}

Section two was aimed at obtaining information regarding retirement saving behaviour and beliefs as well as savings behaviour in general. Items included in this section related to membership of the company's retirement funds, the number of years of contribution to these funds as well as the percentage contribution to the provident fund - employees have a choice in terms of the percentage contribution to the latter, with $5 \%$ being the minimum. Four items related to retirement planning, namely, whether the respondent has calculated how much should be saved for retirement, how many workshops or courses related to retirement planning have been attended, at what age the respondent plans to retire as well as the extent to which the respondent obtains advice from others regarding retirement saving.

An item on respondents' beliefs regarding the sufficiency of their current retirement saving was followed by items related to other retirement and general savings vehicles or products that the respondent voluntarily contributes to. The last items in this section were aimed at gleaning the respondents' risk-taking behaviour (such as gambling, playing the lotto or betting on horses) as well as their perception of their financial risk tolerance (as used by Grable and Lytton, 2001):

How do you rate your willingness to take financial risks compared to others?

- Very low risk-taker

- Low risk-taker

- Average risk-taker

- High risk-taker

- Very high risk-taker

Section three of the questionnaire focused on the attitude towards saving for retirement, the results of which fall outside the scope of this paper, and, hence, are excluded from this discussion. 


\subsection{Sampling strategy and sampling frame}

The population comprised a total of 644 young adults aged between 25 and 35 years working in the particular organisation. All of the young adults in the target population ( $100 \%$ sample) were invited to participate in the survey. The sampling frame was the list of email addresses obtained, with permission, from the human resources department of the organisation.

\subsection{Research procedure and ethical requirements}

The survey was conducted from 1 September 2010 until 1 October 2010. A survey link (http://surveys.g3research.co.za/index.php?sid=24482\&lang=en) was sent via email to the respondents. The respondents were directed to a website in order to complete the questionnaire by clicking on the survey link. Two notifications (i.e. reminders) were sent to the respondents before the survey was closed.

The study complied with ethical requirements in research:

1) No potentially sensitive questions were asked (a pilot study was conducted to check the wordings of the questions);

2) Participants were informed of the purpose of the survey in the cover letter that accompanied the invitation to participate;

3) Participation was voluntary: there was no obligation or incentive to complete the questionnaire and

4) Respondent rights to anonymity and confidentiality were respected.

\section{DISCUSSION OF RESULTS}

\subsection{Bio- and demographic profile}

The response rate was $18.32 \%$ (i.e. 118 of 644 ). The response rate is comparable with online surveys: a survey conducted in the Netherlands for the purpose of an experimental study on response rate and response quality of internet-based surveys using incentives yielded a response rate of $20.4 \%$ (Deutskens et al., 2004). Another study on the comparison of web-based and mail surveys response rates yielded a response rate of $20.7 \%$ as far as the web-based survey was concerned (Kaplowitz et al., 2004). TABLE 2 provides a comparative summary of the bioand demographic characteristics of the sample $(n=118)$ and of the population $(N=644)$. In comparison with the population, females in the sample were slightly over-represented. This implies that females in the population were more likely than their male counterparts to participate in the survey. Married or co-habiting individuals were somewhat over-represented in the sample, while the percentage of respondents who are single or divorced was similar to the population percentage. In addition, the sample consisted of a larger percentage of permanent employees $(96.6 \%)$ than in the population $(86.8 \%)$ and a larger percentage of supervisors (33.9\%) than in the population (14.4\%). In terms of the other background questions, $10.2 \%$ of respondents have a postgraduate qualification, while $17.8 \%$ have an undergraduate degree and the largest percentage ( $42.4 \%$ ) have a national diploma. In terms of number of dependants, the majority ( $71.2 \%$ ) have at least one dependant (i.e. one, two, three or more). In addition, $45.8 \%$ have two or more people financially dependent on their income. Despite the relatively low 
response rate and the discrepancies between the sample and the population, the sample of respondents represented the various biographic and background characteristics of the 25 to 35 years employed at the organisation. The under-representation of general staff in the sample implies that the sample results are more likely to reflect the behaviours of those in a higherincome category due to the fact that general staff members, on average, earn less than supervisors and managers. In addition, the majority of respondents in the sample are permanent staff members who are obliged to contribute to the organisation's retirement funds (pension fund and provident fund).

TABLE 2: Comparison of background information of population and sample

\begin{tabular}{|c|c|c|c|}
\hline Variables & Variable categories & $\begin{array}{c}\text { Population } \\
\text { percentage } \\
\text { of } 644\end{array}$ & $\begin{array}{c}\text { Sample } \\
\text { percentage } \\
\text { of } 118\end{array}$ \\
\hline \multirow[t]{6}{*}{ Race } & Black & 32.6 & 23.7 \\
\hline & Indian & 23.8 & 22 \\
\hline & Coloured & 9 & 8.5 \\
\hline & White & 34.2 & 45.8 \\
\hline & Asian & 0.5 & 0 \\
\hline & Total & 100 & 100 \\
\hline \multirow[t]{3}{*}{ Gender } & Male & 50.5 & 36.4 \\
\hline & Female & 49.5 & 63.6 \\
\hline & Total & 100 & 100 \\
\hline \multirow[t]{5}{*}{ Marital Status } & Married or co-habiting & 39.6 & 51.7 \\
\hline & Single or Divorced & 53.3 & 48.3 \\
\hline & Widowed & 0.3 & 0 \\
\hline & Unknown & 6.8 & 0 \\
\hline & Total & 100 & 100 \\
\hline \multirow[t]{4}{*}{ Employment Status } & Permanent & 86.8 & 96.6 \\
\hline & Contract & 11.6 & 3.4 \\
\hline & Part time & 1.6 & 0 \\
\hline & Total & 100 & 100 \\
\hline \multirow[t]{5}{*}{ Job Level } & Manager & 10.9 & 12.7 \\
\hline & StaffM & 74.7 & 51.7 \\
\hline & Supervisor(Team leader,Technical Specialist) & 14.4 & 33.9 \\
\hline & Unknown & & 1.7 \\
\hline & Total & 100 & 100 \\
\hline
\end{tabular}

Source: Authors'calculation

\subsubsection{Indebtedness}

Descriptive statistics of the extent to which the respondents have debt in comparison to their monthly income showed that more than $60 \%$ of the respondents have some form of credit card 
debt, while approximately half of the respondents have some form of car repayment debt $(49.15 \%)$ or home repayment debt $(50.85 \%)$. More than $10 \%(12.7 \%)$ of the respondents have a great deal of debt - i.e. spend more than $30 \%$ of their monthly income on their home loans, while $9.32 \%$ spend more than $30 \%$ of their income on credit card debt. A large proportion of the sample (32\%) have an overdraft on their current account, with $5.93 \%$ having a great deal of debt on their overdraft (more than $30 \%$ of their income). Approximately $39 \%$ have rental debt. The results indicate that the young adults in general tend to be indebted, with the level of indebtedness being large for many of them.

\subsubsection{Retirement saving beliefs and behaviour}

Employees who are permanently employed in this organisation are required by law to contribute to the company's retirement funds (i.e. pension fund and provident fund). The contribution to the pension fund is set at $5 \%$, and the contribution to the provident fund is set at a minimum of $5 \%$ and a maximum of $20 \%$ depending on the preference of the employee. In this study, the majority of the respondents are permanently employed by the organisation, and, therefore, are obliged to contribute to the retirement funds. Due to the fact that $96.6 \%$ of the sample are permanent staff members, nearly all of the sample make a mandatorily contribution to the organisations' retirement fund. Indeed, $72.8 \%$ have contributed to this fund for more than two years. Only seven respondents $(5.9 \%$ of 118$)$ indicated not being a member of the pension fund, and only eight respondents $(6.8 \%$ of 118$)$ indicated that they are not members of their company's provident fund.

In terms of their contribution to the provident fund (see FIGURE 1), 39\% of the respondents contribute the minimum amount (that is, $5 \%$ ) only while $34.7 \%$ contribute slightly more, namely $7.5 \%$. Only a small percentage $(7.6 \%$ ) contributed more than $7.5 \%$ of their income, while $11.9 \%$ were unsure of their percentage contribution. The latter result may be indicative of a lack of interest in retirement savings.

\begin{tabular}{|l|c|}
\hline \multicolumn{1}{|c|}{$|c|$} \\
\cline { 2 - 2 } \multicolumn{1}{|c|}{} & \\
\hline \multicolumn{1}{|c|}{} & \\
\hline$\square 5 \%$ & Percent \\
\hline$\square 7.5 \%$ & 39.0 \\
\hline$\square 10 \%$ & 34.7 \\
\hline$\square 12.5 \%$ & 4.2 \\
\hline$\square$ I am unsure & 3.4 \\
\hline
\end{tabular}

\section{FIGURE 1: Percentage of contribution to the provident fund}

\section{Source: Authors'calculation}

Although the reason for contributing the minimum rate was not explored in this study, one of the reasons for this behaviour may be that the respondents are not informed by the organisation that they can contribute up to $20 \%$. Another reason may be that employees choose the lowest possible contribution rate just to comply with their employer's policy (Thaler \& Benartzi, 2007). A further reason may be that they cannot afford to contribute more due to debt repayment. As 
indicated previously, large percentages of the respondents have some form of credit card, home loan or car repayment debt as well as debt on an overdraft facility. This result lends support to the statement by Kotze and Smit (2008) that there is an inverse relationship between savings and debt.

Although alarming, the finding that a large percentage of respondents do not save over and above their mandatory contribution is similar to that reported by other authors and researchers. According to Thomas et al. (2009), Kotze and Smit (2008), Strydom (2007) and Shapiro (2004), most young adults do not save for retirement over and above the mandatory contribution.

The respondents' tardiness in actively managing their pension funds is furthermore highlighted by the fact that most respondents $(67.8 \%)$ indicated that they have not changed their percentage contribution to this fund since they became members. This finding corroborates the statement of Burns and Dwyer (2007) and Webster (1997), who noted that individuals do not tend to increase their contribution to a retirement fund.

Despite the low contribution rate to the provident fund, very few of the respondents (only $3.4 \%$ ) believe their pension will to a large extent cover their expenses during retirement. Most respondents believe that their pension will either cover their expenses to a moderate extent $(39.8 \%)$ or to a small extent (39\%) only. This finding indicates that respondents are aware that their retirement fund contributions will not provide sufficient cover during retirement, even though most of them (77.1\%) indicated that they have not done any calculations on how much they should save to have sufficient cover during retirement. This finding corroborates the suggestion of Lusardi (2001), Anthes in Kotze and Smit (2008) and the National Retirement Planning Coalition in Shapiro (2004) that few individuals have determined how much money they should save for retirement.

A large percentage of the respondents (38.1\%) indicated that they do not contribute to retirement products other than the provident or pension fund contribution at the organisation. A substantial percentage (32.2\%) indicated that they do contribute, albeit only less than $5 \%$ of their monthly income to other retirement products, while $29.7 \%$ indicated that they invest more than $5 \%$ of their monthly income in other retirement products such as retirement annuities. The finding suggests an awareness among the young adults of the importance of saving over and above their retirement fund contributions. This notion is supported by the fact that most of the respondents $(93.2 \%)$ believe one should start saving for retirement before the age of 30 .

\subsection{Financial planning}

The previous assertion that the young adults tend to be aware of the need to save for retirement is further supported by the fact that they also seem to be aware of the importance of retirement planning: $56.9 \%$ indicated that they have attended at least one workshop related to retirement planning (26.3\% attended one workshop while $30.6 \%$ attended two or more workshops). Viewed from a different angle, however, this also means that more than $40 \%$ have not attended any workshops on retirement. The respondents may thus lack the knowledge to make informed decisions about their retirement savings. Attending workshops on retirement is only one way of obtaining information about retirement.

On the question about seeking advice about retirement issues, more than half $(53.39 \%)$ of the respondents indicated that they rely to a moderate or large extent on the advice of a financial adviser, while $36.44 \%$ rely to a moderate or to a large extent on the advice of their family. Most respondents do not rely or rely to a small extent only on the advice of friends (85.59\%). In 
addition, more than three-quarters $(78.85 \%)$ do not rely or rely to a small extent only on the advice of colleagues. The result furthermore suggests that the young adults are aware that information regarding retirement planning should be obtained from a person with authority or from a knowledgeable source such as a financial adviser.

The finding that such a large percentage of respondents utilise the advice of a financial planner is, however, surprising, because Burns and Dwyer (2007), Thaler and Benartzi (1999) in Thaler and Benartzi (2007) and Barnes and Taylor (2006) asserted that only a small proportion of people appear to use a professional financial adviser. The reasons for this seeming discrepancy between empirical findings and literature in this regard may be that respondents provided socially acceptable answers, although there is no evidence to confirm this.

A large percentage of the respondents $(40.7 \%)$ are unsure about their expected age of retirement. This finding seems to suggest that young adults do not actively think about their retirement age. About a quarter $(25.4 \%)$ of the respondents indicated that they wish to retire earlier than the maximum age specified by the rules of their retirement fund, while $33.9 \%$ of the respondents indicated that they wish to retire at the maximum age specified by the rules of their retirement fund.

\subsubsection{Other savings behaviour}

As far as other saving behaviour is concerned (illustrated in FIGURE 2), 63.56\% of the respondents indicated having a savings account and just over $55 \%$ have invested in property. Very few of the respondents invest in exchange-traded funds (6.78\%), trade shares on the stock exchange $(10.17 \%)$ or invest in collective investment schemes such as unit trusts $(11.02 \%)$. The result shows that, despite the young age of the respondents, they tend to invest in low-risk asset classes such as cash but tend not to invest in the more risky asset class of equity. As regards the number of other investments, about a quarter of the respondents have one other type of investment $(25.4 \%$ ), while $27.1 \%$ have two other types of investment and $22 \%$ have three other types of investments.

The fact that so many of the respondents indicated that they have a savings account indicates awareness about saving but says nothing about contributions to the savings account, that is whether regular or ad hoc contributions are made to the savings account or what percentage of monthly income is saved. Moreover, owning a property does not mean that the property has been paid in full. Indeed, from the question related to debt, it is reasonable to assume that those who indicated that they own property also have home loan repayments to make.

In FIGURE 3, the respondents' motivation to save is illustrated graphically: the most important motivation being to save for a 'rainy day' (61.86\%) and for retirement (61.02\%). Equally important motivations for saving include saving for a planned financial expenditure and for education. The result indicates that the respondents represent the three types of savers of Capuano and Ramsay (2011), namely, those who save for unforeseen expenses that may be incurred (rainy-day savers), those who save for a specific reason such as education or retirement (instrumental savers) and, of course, the non-savers. Capuano and Ramsay (2011) consider there to be a hierarchy of savers: with sufficient education, non-savers can become instrumental savers, while instrumental savers can become rainy-day savers. 


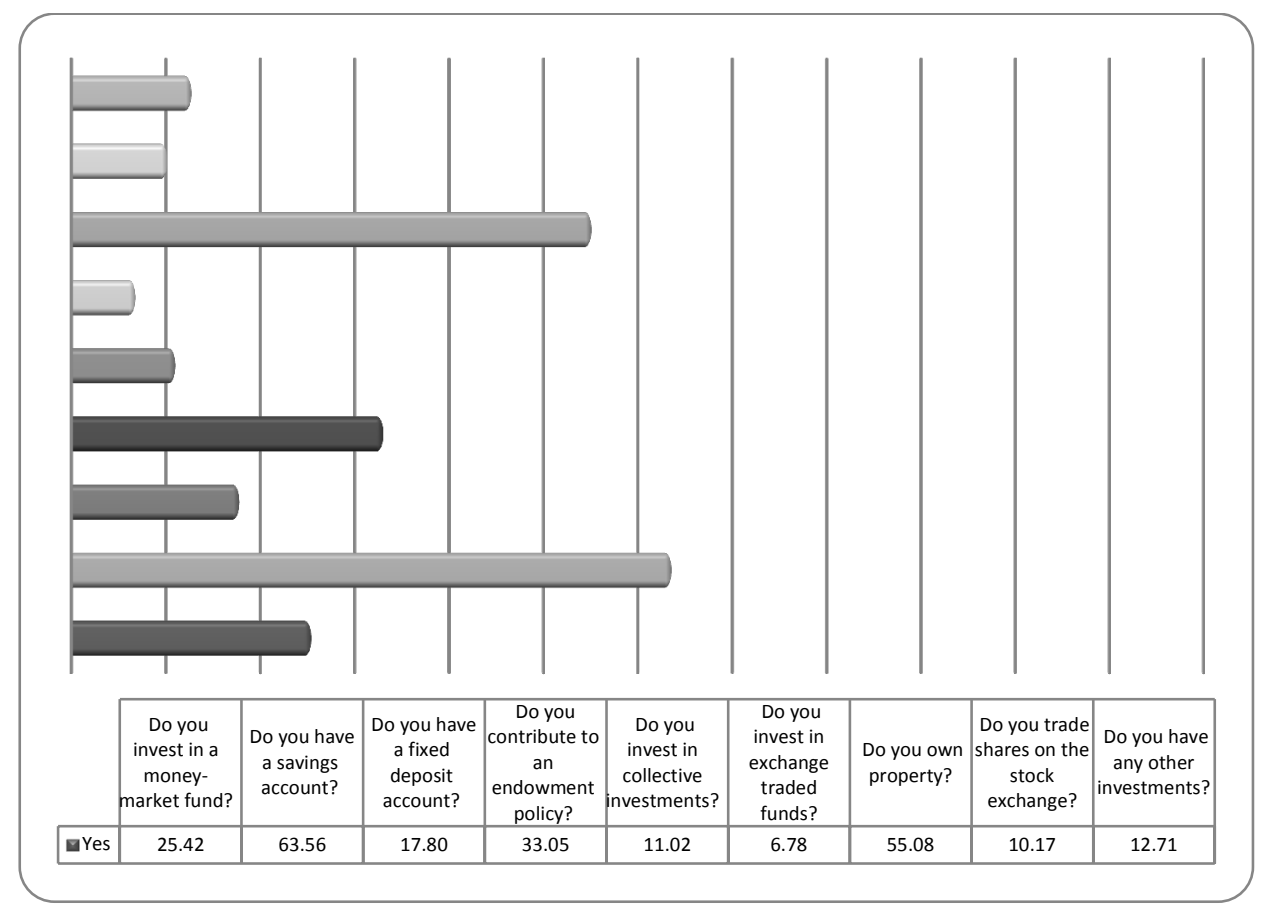

FIGURE 2: Type of investment

Source: Authors'calculation

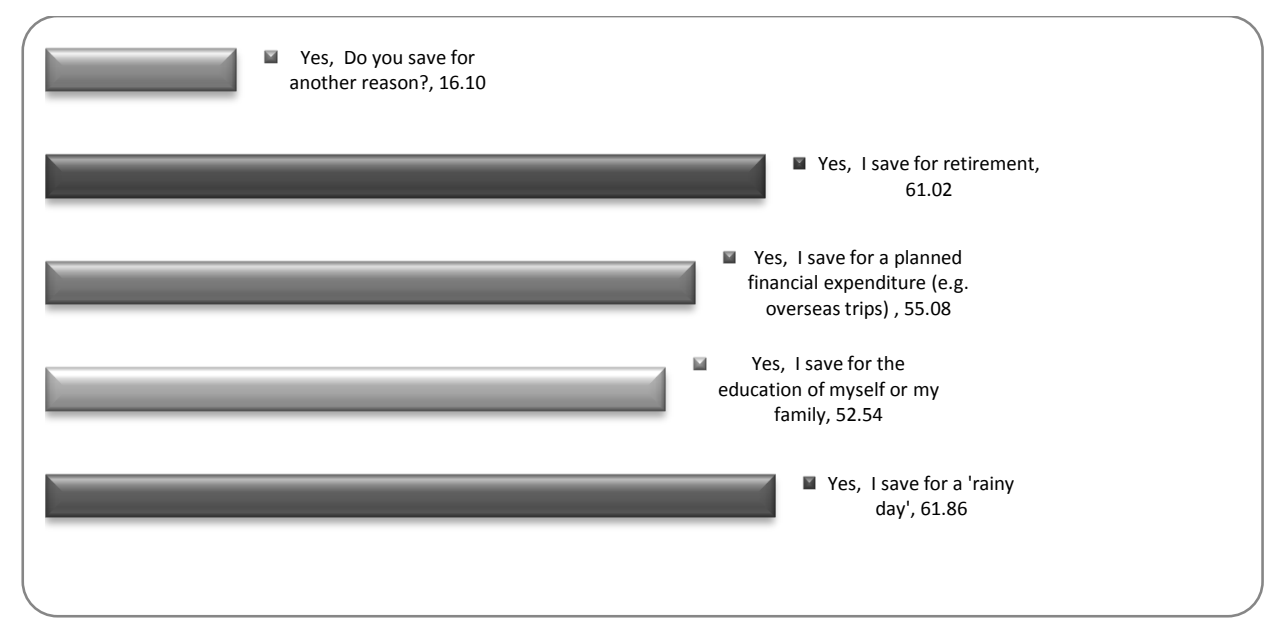

FIGURE 3: Motivation to save

Source: Authors'calculation

\subsubsection{Financial risk-taking behaviour}

As far as risk-taking behaviour is concerned, the vast majority of respondents indicated not 
engaging in risky behaviours: $94.92 \%$ do not bet on horses, $80 \%$ do not gamble at a casino and $64.41 \%$ do not play the lotto. It is well documented that the more tolerant one is to financial risk, the more likely one is to invest in equity (Botha et al., 2008; Shapiro, 2004). As noted previously, most of the respondents did not invest in risky asset classes: less than $10 \%$ invested in exchange-traded funds, and just over $10 \%$ traded shares on the stock exchange. This finding indicates that respondents tend not to take financial risks.

This lack of risk-taking behaviour of the respondents is further highlighted by the fact that very few respondents perceive themselves to be high risk-takers or very high risk-takers ( $5.9 \%$ in total). Most of the respondents describe themselves as either average risk-takers (44.1\%) or low risk-takers (33.1\%). The results in terms of risk-taking behaviour should, however, be viewed in light of the fact that the respondents, despite the fact that their responses were anonymous, did not wish to portray themselves in a poor light and may thus have provided socially acceptable answers.

\subsection{Behavioural differences between groups of respondents}

Given the fact that various bio- and demographic as well as factors such as risk tolerance have been shown in the literature to be related to retirement saving, the null hypothesis of independence between each behavioural question and each of the background questions was tested against the alternative hypothesis that there is a dependency. The chi-square test of independence was used to test the hypotheses, and a minimal significance level of $5 \%$ was assumed throughout. The null hypothesis of independence was rejected in very few cases. Those that were significant are discussed in more detail in the following sections.

\subsubsection{Gender}

The null hypothesis of independence between gender and reliance on the advice of a financial adviser regarding retirement planning was rejected $\left(\chi^{2}(2)=7.688\right.$; $p$-value $\left.=.021<.05\right)$. While a large percentage of males (41.9\%) do not rely on the advice of a financial adviser, more than $75 \%$ of females rely on the advice of a financial adviser to some extent. This implies that female individuals are more likely than male individuals to rely on the advice of a financial adviser regarding retirement planning. The finding suggests that females may be less confident than males about retirement planning, and, hence, are more likely to seek the advice of a financial adviser in this regard.

Adami and Gough (2008) claimed that gender does not have a significant impact on saving for retirement, while Hershey et al. (2008) asserted that male individuals tend to save a greater percentage of their annual income than female individuals. From the discussion above, it is evident that no clear evidence was obtained in this study regarding differences between males and females in terms of their retirement saving behaviour. Hence, this finding fails to reveal whether males are more likely than females to save, as reported by Hershey et al. (2008).

\subsubsection{Financial responsibility}

As far as financial responsibility and reliance on the advice of a financial adviser regarding retirement planning is concerned, the null hypothesis of independence was rejected $\left(\chi^{2}(4)=\right.$ $15.087 ; p$-value $=.005<.05)$. A higher percentage of respondents who have no dependants $(29.4 \%)$ or one dependant only $(30 \%)$ than respondents who have two or more dependants $(3.7 \%)$ rely on the advice of a financial adviser to a small extent, while a higher percentage of 
respondents who have two or more dependants (66.7\%) than respondents who have no dependants $(38.2 \%)$ or one dependant only $(46.7 \%)$ rely on the advice of a financial adviser to a moderate or to a large extent.

This finding may be a result of the fact that individuals in this sample who have at least one dependant were also more likely than those who have no dependants to be married or cohabiting; it is reported that married people are more likely to be interested in retirement issues than unmarried people (Mutran et al. in Foster, 2008; Turner, 1989). This finding provides support for the claim made by Nzier (2007) that young adults with responsibilities such as raising a child tend to pay attention to financial planning, compared to those with few or no responsibilities. It suggests that increased financial responsibility is associated with effective retirement planning.

In terms of financial responsibility and attendance of workshops/courses related to retirement planning, the null hypothesis of independence was rejected $\left(\chi^{2}(2)=6.801 ; p\right.$-value $=.033<$ $.05)$. A higher percentage of respondents who have one dependant $(66.7 \%)$ or two or more dependants $(63 \%)$ than respondents who have no dependant $(38.2 \%)$ have attended at least one workshop/course related to retirement planning. Hence, those who have at least one dependant are more likely than those who have no dependants to be concerned about planning for retirement. This result provides additional support to the statement that that increased financial responsibility is associated with effective retirement planning.

\subsubsection{Level of education}

The null hypothesis of independence between level of education and attendance of workshops/courses related to retirement planning was rejected $\left(\chi^{2}(2)=6.247\right.$; $p$-value $=.044<$ $.05)$. While a high percentage of the respondents with a national diploma (70\%) have attended at least one workshop/course related to retirement planning, more than $50 \%$ of those with a matric or lower $(51.4 \%)$ or an undergraduate or a postgraduate qualification (54.5\%) have attended no workshops/courses.

Although individuals with a low level of education have been reported to be less likely to save for retirement, no clear evidence was thus obtained in this study regarding difference between the different levels of education groups in terms of their retirement saving behaviour. The assertion of Dummann (2008) that individuals with a low level of educational background are less likely to make provision for retirement could not be supported.

\subsubsection{Job level}

As far as job level and purchasing of exchange-traded funds is concerned, the null hypothesis of independence was rejected $\left(\chi^{2}(3)=8.550 ; p\right.$-value $\left.=.036<.05\right)$. A higher percentage of technical staff $(15 \%)$ or managerial staff $(20 \%)$ than general staff $(1.7 \%)$ or team leader staff (5.3\%) invest in exchange-traded funds.

From the literature, the influence of job level on retirement saving behaviour remains inconclusive: some authors and researchers believe that individuals in senior positions are more interested in saving for retirement (Beck in Turner, 1989), while others assert that those in middle or junior positions are more likely to be interested in retirement saving (Kerckhoff \& Simpson in Goudy et al., 1980). Evidence from the current study suggests that individuals in managerial positions are more associated with investing in the riskier asset class of equity. Investing in equity is generally considered to be a more risky investment than investing in 
property or government bonds, for example. It may be that individuals in managerial positions, compared to general staff, are likely to be less averse to risk due to the fact that they earn higher salaries. The fact that individuals in managerial positions tended to invest in exchangetraded funds may also be as a result of them being more likely to be familiar with this type of investment instrument, or that they may be aware that it is more prudent to invest in riskier asset classes at a young age than when close to retirement age. It is, however, not clear from this finding whether people in senior positions are more interested than people in middle or junior positions in saving for retirement, as reported by Beck in Turner (1989) and Heron \& Burgess in Goudy et al. (1980).

\section{CONCLUSION AND RECOMMENDATIONS}

This research paper provided an insight into the retirement saving behaviour of young adults in the financial services sector. The findings revealed that a large percentage had not calculated how much they should save for retirement. Young adults tended not to save over and above their contributions to a retirement fund. Mandatory contributions to the retirement fund of an organisation forces employees to save for retirement. However, the mandatory contributions may create a false sense of complacency among employees of being financially secure at retirement. If employees are not sufficiently informed, either by the government or by their employing organisation, or both, that mandatory contributions do not guarantee the continuation of the same lifestyle after retirement as before, the employing organisation and the government are failing in their duties. Employing organisations have a duty to advise their employees of the importance to save over and above their mandatory contributions. In addition, employers may offer support services to help employees to plan properly for retirement through personal debt reduction and additional savings or investments. The support services may include information sessions at the time the employee joins the organisation's retirement fund and regular workshops or courses related to retirement planning. These sessions should, inter alia, highlight trends in medical costs and insurance, trends in food and travel costs; inflation; life expectancy; the impact of these on retirement savings; how to calculate how much should be saved for retirement, to name but a few. Efforts by organisations to inform and educate employees about retirement and retirement finance should not be aimed only at those nearing the retirement age but also at younger individuals as well. Indeed, employees in the age group 25-35 may be encouraged to invest some of their savings in asset classes other than cash, such as equity, which will result in better returns in the long term. If employing organisations and the government can mobilise employees through these efforts to actively plan and save for retirement, it will contribute to increasing the percentage of financially independent South African retirees.

\section{LIST OF REFERENCES}

Adami, R. \& Gough, 0. (2008). Pension reforms and saving for retirement: comparing the United Kingdom and Italy. Policy Studies, 29(2), pp. 119-135.

Bailey, J.J., Nofsinger, J.R., \& O'Neill, M. (2003). A review on major influences on employee retirement investment decisions. Journal of financial services research, 23(2), pp. 149-165.

Bajtelsmit, V. (2006). Personal finance skills for life. United States of America: John Wiley \& Sons, Inc. 
Barnes, H. \& Taylor, R. (2006). Work, saving and retirement among ethnic minorities: A qualitative study. Research report, 396. [0n-line] Available: www.dwp.gov.uk/asd/asd5/rrs-index.asp.

(Accessed 25 September 2009)

Botha, M., Du Plessis, C., Du Preez, L., Geach, W., Nel, Z., Rossini, L. \& Linde, G. (2008). The South African financial planning handbook. South Africa: LexisNexis.

Burns, J. \& Dwyer, M. (2007). Households' attitudes to saving, investment and wealth. Reserve Bank of New Zealand Bulletin, 70(4). [On-line] Available:

http://www.rbnz.govt.nz/research/bulletin/2007_2011/2007dec70_4burnsdwyer.pdf.(Accessed 25 September 2009)

Capuano, A. \& Ramsay, I. (2011). What causes suboptimal financial behaviour? An exploration of financial literacy, social influences and behavioural economics. Financial Literate research project: Research report. The University of Melbourne. [0n-line] Available: www.discoveryhealth.co.za. (Accessed 9 September 2011)

Deutskens, E., De Ruyter, K., Wetzels, M., \& Oosterveld, P. (2004). Response rate and response quality of internet-based surveys: an experimental study. Journal of marketing letters, 15(1), pp. 21-36.

Dulebohn, J. H. \& Murray, B. (2008). Understanding risk taking in retirement savings through attitude. Trends and issues, November 2008. [On-line] Available: http://www.tiaa-

crefinstitute.org/pdf/research/trends_issues/tr1 10108.pdf. (Accessed 25 September 2009)

Dummann K. (2008). Retirement saving attitude towards financial intermediaries, evidence for Germany. University of Rostock Department of Economics Working Paper, 99 (November 2008 version). [On-line] Available: http://www.wiwi.uni-rostock.de/fileadmin/Institute/VWL/VWLInstitut/RePEc/pdf/wp99thuenen.pdf. (Accessed 24 August 2009)

Foster, T. (2008). Depression, anxiety and attitude towards retirement as predictors of wellness for workers nearing retirement. Doctoral dissertation. Ohio: Kent University. [On-line] Available: http://www.ohiolink.edu/etd/sendpdf.cgi/Foster\%20Thomas\%20Wayne.pdf?acc_num=kent1216220458. (Accessed l July 2009)

Genesis Analytics (2008). Old age saving by low-income South Africans. South African Savings Institute, March 2008. [On-line] Available:

http://www.savingsinstitute.co.za/pdf/SA_LSM1_5_old_age_savings_Genesis_final.pdf. (Accessed 1 March 2009)

Goudy, W.J., Powers, E.A., Keith, P.M., \& Reger, R.A. (1980). Changes in attitudes towards retirement: evidence from a panel study of older males. Journal of Gerontology, 35(6), pp. 942-948.

Grable, J.E. \& Lytton, R.H. (2001). Assessing the concurrent validity of the SCF risk tolerance question. Financial counseling and planning, 12(2), pp. 43-53.

Hershey, D.A., Jacobs-Lawson, J.M., McArdle, J.J., \& Hamagami, F. (2008). Psychological Foundations of Financial Planning for Retirement. Journal of Adult Development, 14(1-2), pp. 26-36.

Kaplowitz, M.D., Hadlock, T.D., \& Levine, R. (2004). A comparison of web and mail survey response rates. Journal of public opinion, 68(1), pp. 94-101.

Kotze, L. \& Smit, A.V.A. (2008). Personal finances: What is the possible impact on entrepreneurial activity in South Africa? Southern African Business Review, 12(3), pp. 156-172.

Lusardi, A. (2001). Explaining why so many people do not save. Centre for Retirement Research Working Paper, 2001-5. Available from: http://crr.bc.edu/images/stories/Working_Papers/wp_200105.pdf?phpMyAdmin=43ac483c4de9t5ld9eb4l. (Accessed 21 November 2009) 
Nzier (2007). Young people's attitudes towards consumption and saving. [0n-line] Available: http://www.retirement.org.nz/files/retirement-

files/Younger_peoples_attitudes_towards_consumption_and_saving.pdf. (Accessed 5 June 2009)

Prinsloo, J.W. (2000). The saving behaviour of the South African economy. Reserve Bank Occasional Paper, 14. [0n-line] Available:

http://www.reservebank.co.za/internet/Publication.nsf/LADV/8372AC83948E3B8042256B6C003B92C A/\$File/occl4fin.pdf. (Accessed 21 February 2010)

Shapiro, D. (2004). Retirement countdown: take action now to get the life you want. New Jersey: FT Prentice Hall.

Snyder, M (2010). 22 statistics about the coming pension crisis that will keep you up at night. August 2010. [On-line] Available: http://www.businessinsider.com/scary-facts-about-the-comingpension-crisis-2010-8. (Accessed 19 July 2011)

South African Reserve Bank (2011). Quarterly bulletin, June 2011. [0n-line] Available: http://www.resbank.co.za/Lists/News\%20and\%20Publications/Attachments/4677/Full\%20Quarterly \%20Bulletin\%20-\%20June\%202011.pdf. (Accessed 30 August 2011)

South African Reserve Bank (2010). Quarterly bulletin, March 2010. [On-line] Available: http://www.reservebank.co.za/internet/Publication.nsf/LADV/92A620ACD595CF42422576EBB00555EF 5/\$File/QBMarch2010.pdf. (Accessed 12 April 2010)

South African Reserve Bank (2009). Quarterly bulletin, December 2009. [On-line] Available: http://www.reservebank.co.za/internet/Publication.nsf/LADV/78A8B0E76CFA3A83422576870049F7B B/\$File/QBDec09+.pdf. (Accessed 12 April 2010)

Statistics South Africa (2005). Census 2001, stages in a life cycle of South Africans. [0n-line] Available: http://www.statssa.gov.za/census01/html/C2001Stages.pdf. (Accessed 200 ctober 2009)

Statistics South Africa (2009). Mid-year population estimates 2009. Statistical release P0302. [Online] Available: http://www.statssa.gov.za/publications/P0302/P03022009.pdf. (Accessed 7 April 2010)

Strydom, P. (2007). Saving behaviour by South African households. First National Bank Economic Services, April 2007. [On-line] Available:

https://www.fnb.co.za/economics/econhtml/docs/SavingHouseholds.pdf. (Accessed 2 November 2009)

Thaler, R.H. \& Benartzi, S. (2007). The behavioural economics of retirement savings behaviour. The AARP public policy institute, January 2007. [On-line] Available:

http://www.retirementmadesimpler.org/Library/The\%20Behavioral\%20Economics\%20of\%20Retirem ent\%20Savings\%20Behavior\%20-\%20Full.pdf. (Accessed 25 September 2009)

Thomas, A., Jones, J., Davies, S., \& Chilvers, D. (2009). Individuals' attitudes and behaviours around planning and saving for later life, findings from qualitative and quantitative research. Department of Work and Pensions working paper, 72. [On-line] Available: www.dwp.gov.uk/asd/asd5/rrs-index.asp. (25 September 2009)

Turner, M.J. (1989). Factors influencing attitude towards retirement and retirement planning among mid-life university employee. Doctoral dissertation. Texas: Texas graduate Tech University. [0n-line] Available: http://etd.lib.ttu.edu/theses/available/etd-0226200931295005915870/unrestricted/31295005915870.pdf. (Accessed l May 2009) 
Webster, $\varepsilon$. (1997). Householder attitudes towards retirement incomes, Australia, 1997. Melbourne Institute of Applied Economic and Social Research working paper, 15/97. [On-line] Available: http://www.ecom.unimelb.edu.au/iaesrwww/home.html. (Accessed l May 2009)

Wills, L. \& Ross D. (2002). Towards a model of the personal retirement savings decision. The Pension Institute, Cass Business School \& City University Discussion paper, P10306. [On-line] Available: http://www.pensions-institute.org/workingpapers/wp0306.pdf. (Accessed 24 August 2009) 